\title{
Growth rate and behavior of Norway rats reared on conspecific flesh
}

\author{
W. J. CARR \\ Beaver College, Glenside, Pennsylvania 19038 \\ and \\ M. R. LANDAUER \\ Medical College of Virginia, Virginia Commonwealth University, Richmond Virginia 23298
}

\begin{abstract}
In an effort to establish the adaptive significance of their aversion to feed on dead adult conspecifics, Norway rats were reared from birth on commercial lab chow or on dead adult conspecifics ( $n=12$ males and 18 females per group). At 12 weeks of age, those reared on lab chow weighed reliably more $(p<.01)$ than those reared on conspecific carcasses. The difference in weight between the two groups (5.4\%) was equivalent to 1 week's growth in rats 10-12 weeks old. Those reared on lab chow also drank reliably more water $(p<.001)$. Females reared on conspecific carcasses produced reliably fewer pups per litter $(p<.002)$; otherwise, their maternal behavior was normal. These findings cast doubt on two hypotheses: (1) Hungry rats commonly reject conspecific flesh as food because it is nutritionally inadequate, and (2) feeding on dead conspecifics potentiates preying on live ones.
\end{abstract}

Many mammalian flesh eaters living in their natural environment are said to treat the intact carcass of a dead adult conspecific as suboptimal food, sometimes rejecting it entirely, especially if the conspecific has been dead only a short time (Božkov, 1968; Dawkins, 1976, pp. 89-90; Lorenz, 1966, p. 120; Polis, in press). We view this phenomenon as a special type of food aversion, here defined as the tendency by a large majority of hungry animals to remain hungry rather than feed on a dead conspecific, coupled with the tendency by a large majority to feed on comparable nonconspecific flesh rather than remain hungry. (For a similar definition of the term "food aversion," see Rozin, 1976.) The aversion may also manifest itself in reliably longer latencies to begin feeding on a dead conspecific than on a nonconspecific and in reliably smaller amounts consumed from the former than from the latter carcass. Such a food aversion has been demonstrated under laboratory conditions in domestic dogs, albeit with varying degrees of precision (Girden, 1932; Maslow, 1932; Schiff, 1860; Sherrington, 1947, pp. 262-263).

Norway rats clearly exhibit an aversion to feed on dead adult conspecifics. For example, a majority (12 of 16) of hungry Norway rats remained hungry rather than feed within $30 \mathrm{~min}$ on the intact carcass of a freshly sacrificed adult conspecific, whereas a majority ( 8 of 11 ) fed within $30 \mathrm{~min}$ on a freshly sacrificed roof rat (Rattus rattus), a congeneric species quite comparable to the Norway rat in size and other external characteristics (Carr, Landauer, Wiese, Marasco, \& Thor, 1979). A majority (28 of 32 ) of Norway rats also fed within 30 min on a dead house mouse (Mus musculus) (Carr, Schwartz, Chism, \& Thomas, 1981). Likewise, a majority
(14 of 19) of hungry house mice rejected a dead adult conspecific and fed instead on a dead rat (Carr et al., 1981). Taken together, these findings suggest that neither rat nor mouse flesh is inherently distasteful in the sense that quinine is distasteful to most species. Rather, the feeding behavior of each species is species dependent; that is, members of each species tend to reject their own dead as food.

Considerable evidence supports the view that the aversion by Norway rats to feed on dead adult conspecifics is mediated, at least in part, by the same chemical signal(s) that also mediate(s) species recognition (Carr, Hirsch, Campellone, \& Marasco, 1979; Carr, Dissinger, \& Scannapieco, Note 1). Contrary to a popular view, adult male rats even exhibit an aversion to feed on dead conspecific young (aged 6-9 days), provided that the subjects had cohabited with other conspecific young until shortly before testing (Carr, Bell, Messori, \& Erlichman, Note 2).

Among many invertebrates and fishes, feeding on dead conspecifics and even preying on live ones are so common as to be viewed by some (e.g., Fox, 1975; Polis, in press; Wilson, 1971) as normal food-getting behavior. Yet, among mammals, the tendency to reject dead adult conspecifics as food is generally considered to be the norm, and the acceptance of such flesh is viewed as abnormal behavior, requiring some special explanation (e.g., Green, 1925; Lorenz, 1970b, p. 94; Young, 1936, p. 108). But we agree with Dawkins (1976, p. 89) and Harris (1979), who argue that the fundamental issue is not why a few mammals accept conspecific flesh, but, rather, why the great majority reject it. 
In a world in which animal protein is sometimes scarce, what advantage is to be gained by remaining hungry rather than feeding on a dead conspecific? Why permit the protein to pass on to other species in the food chain? Indeed, some suggest that conspecific flesh should be ideal food for a flesh eater, because it consists of the same materials of which the feeder is composed, and in the same proportions (Adolph, 1967; Errington, 1967, p. 58; Harris, 1979; Lorenz, 1970a).

But there may be some subtle, deleterious effect of feeding on conspecific flesh, heretofore undetected because so little research has been done on the topic. If so, such an effect is most likely to manifest itself in animals whose diet consisted chiefly of conspecific flesh during the period of rapid growth from birth to early adulthood. To test this interesting possibility, we measured the growth rates of two groups of rats, one reared on commercial lab chow and the other on the carcasses of adult conspecifics. We also observed the maternal behavior of females subjected to one of the two diets in order to determine if feeding on dead conspecifics potentiates feeding on live neonates, as was suggested by Lorenz (1970a).

\section{METHOD}

\section{Subjects and Apparatus}

The subjects were 60 Norway rats (Long-Evans), born in our laboratory of stock acquired from Perfection Breeders (Douglassville, Pennsylvania). From birth until weaning at 4 weeks of age, the rats lived with their dams in hardware cloth cages $(25 \times 38 \times 71 \mathrm{~cm})$ lined with wood-chip bedding. Thereafter, they lived in like-sex groups of four to five in the same type of cage. At birth, the litters were assigned randomly to one of two treatment groups (12 males and 18 females per group), differing only with respect to the type of feed available. One group had constant access to water and lab chow pellets (Charles River). The other group had constant access to water and the carcass of an adult conspecific, sacrificed by cervical dislocation. New carcasses were supplied before the old ones were consumed completely, usually every day or every other day. Throughout the experiment, the rats lived in a temperature controlled room $\left(21^{\circ} \mathrm{C}-22^{\circ} \mathrm{C}\right)$ on a $12: 12 \mathrm{~h}$ light/dark cycle.

\section{Procedure}

In order to compare their growth rates, we weighed each rat in the two treatment groups weekly from the 4 th through the 12 th weeks of life. Thereafter, 10 females and 7 males were selected randomly from each group and were retained on their diet in order to determine its effect on maternal behavior and water intake. At 4 months of age, the 10 females in each group were paired with sexually vigorous males. On the day of parturition, their pups were counted and then the litters were reduced (as necessary) to eight pups and equated for sex as closely as possible. The litters were examined daily until weaning at 4 weeks of age. At 4 months of age, the seven males in each group were housed individually and their daily water intake was measured for 4 consecutive days.

\section{RESULTS AND DISCUSSION}

\section{Growth}

Table 1 shows the increase in mean body weight during the 4 th through 12 th weeks of life for the rats
Table 1

Mean Weight (in Grams) of Rats Reared on Lab Chow or Rat Carcasses

\begin{tabular}{cccccc}
\hline \multirow{2}{*}{$\begin{array}{c}\text { Age } \\
\text { (in Weeks) }\end{array}$} & \multicolumn{2}{c}{ Reared on Lab Chow } & & \multicolumn{2}{c}{ Reared on Carcasses } \\
\cline { 2 - 3 } \cline { 5 - 6 } & $\begin{array}{c}\text { Males } \\
\text { N = 12) }\end{array}$ & $\begin{array}{c}\text { Females } \\
(\mathrm{N}=18)\end{array}$ & $\begin{array}{c}\text { Males } \\
(\mathrm{N}=12)\end{array}$ & $\begin{array}{c}\text { Females } \\
(\mathrm{N}=18)\end{array}$ \\
\hline 4 & 47.6 & 45.3 & 48.2 & 47.2 \\
6 & 106.1 & 102.6 & 103.4 & 94.1 \\
8 & 182.8 & 152.0 & 167.7 & 137.5 \\
10 & 242.0 & 188.8 & 200.4 & 172.0 \\
12 & 267.5 & 212.3 & 252.9 & 201.8 \\
\hline
\end{tabular}

raised on lab chow vs. conspecific carcasses. A 2 by 2 by 9 ANOVA (diet by sex by age) with repeated measures on the third factor revealed significant main effects on body weight attributable to diet $[\mathrm{F}(1,56)=10.23$, $\mathrm{p}<.003]$, to sex $[\mathrm{F}(1,56)=37.22, \mathrm{p}<.001]$, and to age $[F(8,448)=1,862.09, p<.001]$. The analysis also revealed significant interactions between sex and age $[F(8,448)=44.13, p<.001]$ and between diet and age $[F(8,448)=15.03, p<.001]$, the latter indicating a cumulative deleterious effect on body weight due to feeding on conspecific flesh. Finally, a significant triple interaction $[\mathrm{F}(8,448)=2.81, \mathrm{p}<.003]$ indicates that the cumulative deleterious effect inhibits growth more in males than in females. Slonaker and Card (1923) reported a similar sex-linked difference in rats subjected to dietary restriction.

At 12 weeks of age, the mean body weight of the rats raised on lab chow was $5.4 \%$ greater than that of the rats raised on conspecific flesh (234.4 vs. $222.2 \mathrm{~g}$ ). But during the last 2 weeks of the experiment, the rats raised on lab chow increased their body weights by $5.8 \%$ per week. Therefore, the cumulative deleterious effect stemming from 9 weeks of feeding exclusively on conspecific flesh is approximately equal to 1 week's growth in rats that are 10-12 weeks old. Viewed in this light, the deleterious effect of constant feeding on conspecific flesh seems moderate, and the effect of an occasional meal consisting of such flesh is likely to be beneficial, relative to going without a meal entirely.

\section{Maternal Behavior}

All of the females paired with males produced litters, but the 10 females raised on lab chow delivered reliably more pups $(\mathrm{N}=126$, range $=9-15)$ than did the 10 females raised on conspecific carcasses $(\mathrm{N}=83$, range $=$ 3-12) [Mann-Whitney U test, $\mathrm{U}(10,10)=6.5, \mathrm{p}<.002]$. One female raised on lab chow killed her entire litter when the pups were 17 days old. All other females exhibited normal maternal behavior (e.g., nest building and retrieval of young) and maintained their litters until weaning. Therefore, although females raised exclusively on conspecific carcasses tend to produce fewer pups per litter, such a diet does not seem to potentiate killing and consuming defenseless young, as was suggested by Lorenz (1970a). Indeed, Slonaker and Card 
(1923) found that female rats maintained on a meatfree diet were more likely to consume their young than were females maintained on the same diet, but aug. mented with meat.

\section{Water Intake}

Due, no doubt, to the difference in the water content of the two diets, the rats raised on lab chow drank reliably more water per day (mean $=46.3 \mathrm{ml}, \mathrm{SE}=1.8$ ) during the 4 days of testing than did the rats raised on conspecific carcasses (mean $=17.8 \mathrm{ml}, \mathrm{SE}=1.6$ ) $[\mathrm{t}(12)=11.72, \mathrm{p}<.001]$.

We conclude that Norway rats raised on conspecific carcasses develop rather normally and exhibit no obvious structural or behavioral deficiencies. Therefore, there is little reason to believe that rats living in their natural environment commonly reject conspecific flesh as food (Calhoun, 1962, pp. 238-239; Steiniger, 1950) because it is nutritionally inadequate. Moreover, the relatively normal maternal behavior exhibited by the females raised on conspecific carcasses provides no support for the suggestion made by Lorenz (1970a) that feeding on dead conspecifics may potentiate preying on live ones. Carr, Choi, Sterling, Arnholt, and DeMarco (Note 3) also observed that feeding on dead conspecifics did not induce male rats to prey on live conspecifics aged 17-22 days.

Polis (in press) suggested that the aversion to feed on dead conspecifics may serve to minimize exposure to parasites and pathogens, and he cites 12 instances in which feeding on conspecifics forms a vector for the transmission of an infectious disease. The present findings do not rule out this possible explanation of the tendency by rats and other flesh-eating animals to reject dead adult conspecifics as food.

\section{REFERENCE NOTES}

1. Carr, W. J., Dissinger, M. L., \& Scannapieco, M. R. The stimulus-basis of a natural food aversion in Norway rats. Manuscript submitted for publication, 1981. (Available from W. J. Carr, Department of Psychology, Beaver College, Glenside, Pennsylvania 19038.)

2. Carr, W. J., Bell, A., Messori, E., \& Erlichman, T. Feeding on conspecific neonates: The effects of previous social experience. Unpublished manuscript, 1981. (Available from W. J. Carr, Department of Psychology, Beaver College, Glenside, Pennsylvania 19038.)

3. Carr, W. J., Choi, S. Y., Sterling, M. H., Arnholt, E., \& DeMarco, A. The effect of diet on a natural food aversion in Norway rats. Unpublished manuscript, 1981. (Available from W. J. Carr, Department of Psychology, Beaver College, Glenside, Pennsylvania 19038.)

\section{REFERENCES}

AdolPh, E. F. Critic's comments. In M. R. Kare \& O. Maller (Eds.), The chemical senses and nutrition. Baltimore: Johns Hopkins Press, 1967.

BožKov, D. K. Essai de catégorisation du phénomène cannibalisme chez le monde animal avec quelques notes sur son importance biologique. Bulgarska Akademiia Na Naukite Sophia Zoologicheski Institut Izvestiia, 1968, 27, 81-101.

Calmoun, J. B. The ecology and sociology of the Norway rat (U.S. Public Health Service Publication No. 1008). Washington, D.C: U.S. Government Printing Office, 1962.

Carr, W. J., Hirsch, J. T., Campellone, B. E., \& Marasco, E. Some determinants of a natural food aversion in Norway rats. Journal of Comparative and Physiological Psychology, 1979, 93, 899-906.

Carr, W. J., Landauer, M. R., Wiese, R. E., Marasco, E., \& ThoR, D. H. A natural food aversion in Norway rats. Journal of Comparative and Physiological Psychology, 1979, 93, 574-584.

Carr, W. J., Schwartz, D., Chism, E., \& Thomas, B. A natural food aversion in Norway rats and house mice. Behavioral and Neural Biology, 1981, 31, 314-323.

Dawkins, R. The selfish gene. New York: Oxford University Press, 1976.

ERrington, P. L. Of predation and life. Ames: Iowa State University Press, 1967.

Fox, L. R. Cannibalism in natural populations. Annual Review of Ecology and Systematics, 1975, 6, 87-106.

Girden, E. S. Cannibalism in dogs. Journal of Comparative Psychology, 1932, 14, 409-413.

Green, H. Perverted appetites. Physiological Reviews, 1925, 5, 336-348.

Harris, M. Our pound of flesh. Natural History, 1979, 88(7), 30-36.

LoRenz, K. On aggression. New York: Harcourt, Brace, \& World, 1966.

Lorenz, K. On killing members of one's own species. Bulletin of the Atomic Scientists, 1970, 26(8), 2-5; 51-56. (a)

LORENZ, K. Studies in animal and human behaviour (Vol. 1). Cambridge: Harvard University Press, 1970. (b)

Maslow, A. H. The "emotion" of disgust in dogs. Journal of Comparative Psychology, 1932, 14, 401-407.

Polis, G. A. The evolution and dynamics of intraspecific predation. Annual Review of Ecology and Systematics, in press.

Rozin, P. The selection of food by rats, humans, and other animals. In J. S. Rosenblatt, R. A. Hinde, E. Shaw, \& C. Beer (Eds.), Advances in the study of behavior (Vol. 6). New York: Academic Press, 1976.

Schiff, J. M. Der erste Hirnnerv ist der Geruchsnerv. Untersuchungen zur Naturlehre des Menschen und der Tiere, 1860, 6, 254-267.

She RRINGton, C. S. The integrative action of the nervous system. (2nd ed.). New Haven, Conn: Yale University Press, 1947.

Slonaker, J. R., \& CARD, T. A. The effect of a restricted diet. V. On mortality, cannibalism, and the sex ratio. American Journal of Physiology, 1923, 64, 297-310.

Steiniger, F. Beitrage zur Soziologie und sonstige Biologie der Wanderratte. Zeitschrift für Tierpsychologie, 1950, 7, 356-379.

Wilson, E. O. Competitive and aggressive behavior. In J. F. Eisenberg \& W. S. Dillon (Eds.), Man and beast. Washington, D.C: Smithsoni?n Institution Press, 1971.

Young, P. T. Motivation and emotion. New York: Wiley, 1936. 